\title{
Financial market reaction to central bank monetary policy communications under an inflation-targeting regime: the case of Brazil
}

\author{
Gabriel Caldas $M$.
}

Central bank communications are important for guiding expectations. For emerging countries, however, research on this issue is scarce. Because Brazil represents an important emerging country under inflation targeting, this paper studies the influence of monetary policy and central bank communications on the term structure of interest rates in Brazil. The study uses ordinary least squares (ols), generalized method of moments (gmm) and vector autoregresion (var) to examine the direction taken by interest rates when affected by central bank communications and monetary policy. The study finds evidence that because economic agents analyse the minutes of the Monetary Policy Committee meetings, monetary policy and central bank communications significantly influence the process of expectations formation for interest rates with different maturities in Brazil. 


\section{I}

\section{Introduction}

Keeping inflation low and stable requires credible, committed and transparent policies that guide expectations. According to Blinder and others (2008), as it became increasingly clear that managing expectations is a useful part of monetary policy, communications policy rose in stature from a nuisance to a key instrument in the central banker's toolkit. The analysis of central bank communication is particularly important in emerging economies with an inflation-targeting regime, because the uncertainties about inflation control in such countries (Mishkin and Savastano, 2001) make it more difficult to guide expectations.

According to Blinder and others (2008, p. 940), "communication can be an important and powerful part of the central bank's toolkit since it has the ability to move financial markets". However, empirical evidence is still necessary. As Blinder and others (2008, p. 941) stressed, "The limited number of studies that try to assess the directional intent of the central bank's messages generally find that markets move in the 'right' direction - that is, what used to be called 'announcement effects' help the central bank rather than hinder it. But there has been relatively little such research to date... We need more evidence in order to be convinced on this point, plus further analysis of how, if at all, creating this type of directional news raises welfare".

The literature for developed countries is wide and growing. ${ }^{1}$ Research on emerging countries is scarce, however. This study analyses monetary policy and central bank communication in Brazil. Because Brazil

\footnotetext{
${ }^{1}$ For example, Kohn and Sack (2004); Connolly and Kohler (2004); Musard-Gies (2006); Andersson, Dillén and Sellin (2006); Rosa and Verga (2007); Reeves and Sawicki (2007); Ehrmann and Fratzscher (2007a and 2009); Hayo and Neuenkirch (2010); Brand, Buncic and
}

represents an important emerging country under inflation targeting, and given the increasing relevance of central bank communication, the paper studies the minutes of the Monetary Policy Committee (COPOM) meetings to assess the influence of monetary policy and central bank communications on the short end of the term structure of interest rates.

The study contributes to the literature in the following ways. First, unlike all previous studies on central bank communication, this paper complements the ordinary least squares (OLS) analysis by using generalized method of moments (GMM) and vector autoregression (VAR) to examine the direction taken by interest rates when affected by central bank communications and monetary policy. (To my knowledge, no study uses the VAR methodology to analyse dynamically whether central bank communication influences the direction of interest rates.) Second, the study provides an analysis for the term structure of an important emerging country under inflation targeting, based on the ideas presented in Fuhrer and Moore (1995a and 1995b), Fuhrer (1996) and Walsh (2010). The type of analysis presented in this paper has never been done by any other study on central bank communication.

The paper is organized as follows. Section II presents a brief overview of the literature. Section III uses the minutes of the COPOM meetings to examine the impact of monetary policy and central bank communications on the short end of the term structure of interest rates in Brazil and discusses the empirical results. The last section presents the conclusions.

Turunen (2010); Hayo, Kutan and Neuenkirch (2010); Ranaldo and Rossi (2010); Sturm and de Hann (2011); Rosa (2011); Berger, de Haan and Sturm (2011). 


\section{II}

\section{Central bank communications and monetary policy: literature review}

Inflation targeting was widely adopted in the early 1990s, which heightened awareness of the importance of transparency for the process of expectations formation (Geraats, 2002; de Mendonça and Simão-Filho, 2007). In a forward-looking environment, monetary policy largely becomes an art of managing the expectations of private agents (Woodford, 2003). Consequently, studies about central bank communication have gained importance in the literature on this regime.

The degree of transparency and the regularity of the communication process depend on the level of discretion in the monetary regime adopted. Thus, the complexity of communication is associated with the type of monetary regime adopted. Regimes with less discretion are related to a more simple communication, whereas more flexible arrangements that allow greater discretion, such as inflation targeting, involve more complex communication (Blinder and others, 2008).

Inflation-targeting central banks generally announce four aspects of monetary policy: its objectives and strategies, the reasons behind political decisions, the outlook on the state of the economy and future monetary policy decisions. Since the objectives and strategies of central banks tend to be stable and thus vary less over time than the other three aspects, communications on this aspect are less frequent.

The literature includes two main approaches to analysing the influence of communications on the economy, which are complementary. One explores the impact of central bank communications on financial markets (for example, Kohn and Sack, 2004; Reeves and Sawicki, 2007; Ehrmann and Fratzscher, 2007a and 2009), while the other looks at the influence of different communication strategies among central banks on the economic performance (for example, Fujiwara, 2005; Rozkrut and others, 2007). Since central bank communications influence expectations for the future short-term interest rate, they also affect the long-term rates and, therefore, financial market prices. These prices can, in turn, affect some macroeconomic variables, such as inflation and output. However, while communications and monetary policy instantly affect the financial market, the economy as a whole is affected gradually and by several other factors.
There are basically three approaches to measuring central bank communication. The first seeks to classify all central bank communications according to their content or signals (possible intentions), using a numerical scale to encode these ratings (Jansen and De Haan, 2005; Ehrmann and Fratzscher, 2007b; Rosa and Verga, 2007; Musard-Gies, 2006). Some studies use the codes to indicate direction (Jansen and De Haan, 2005; Ehrmann and Fratzscher, 2007b). The second approach examines all forms of media communication by the Monetary Policy Committee or its members that is relevant for monetary policy (Jansen and De Haan, 2005; Ehrmann and Fratzscher, 2007b). In this case, the task is to extract information from statements, speeches, minutes and reports using a set of search words. When the objective is to assess the trend of monetary policy, the search includes the name of the committee member and the key words interest rate, monetary policy and inflation. When the objective is to assess the future economic environment, the key words are economy and economic outlook. Finally, the third approach takes advantage of some institutional features of the process of announcing monetary policy decisions to measure the impact of communications. An example of this approach is Brand, Buncic and Turunen (2010), who separate the reactions of the financial market into two effects: the monetary policy effect and the communication effect of the European Central Bank.

Different approaches have been developed in the literature to measure the effects of central bank communications (see Blinder and others, 2008, for more details). Starting with Kohn and Sack (2004), some studies have examined the effects of central bank communication events on the volatility of financial variables (Blinder and others, 2008, present several of these studies). The focus on volatility makes it unnecessary to assign a direction to each statement. In other studies, communications are quantified in order to assess both the direction (for example, Ehrmann and Fratzscher, 2007b) and magnitude (for example, Berger and others, 2011) of the effects on asset prices and thus to determine the extent to which a given communication has its intended effects.

In recent years, the general move in central banks to enhance their transparency, accountability and 
communication has motivated a number of studies on the influence of central bank communication on financial markets. ${ }^{2}$ This literature is mostly directed to developed countries, however. For Brazil, Costa Filho and Rocha (2009) discuss the role of communication in the conduct of monetary policy by the Central Bank of Brazil. They build a glossary that translates the qualitative information contained in the COPOM minutes into an ordered scale

2 For example, Kohn and Sack (2004); Connolly and Kohler (2004); Musard-Gies (2006); Andersson, Dillén and Sellin (2006); Rosa and Verga (2007); Reeves and Sawicki (2007); Ehrmann and Fratzscher (2007a and 2009); Brand, Buncic and Turunen (2010); Berger, de Haan and Sturm (2011). index, similar to the one built by Rosa and Verga (2007). They find evidence of consistent behaviour by the COPOM, in the sense that its words are followed by actions in the same direction. Moreover, based on estimates of Taylor rules, they also find evidence that the index helps to understand interest setting. In a later work, (Costa Filho and Rocha, 2010) these authors explore whether better communication from the Central Bank of Brazil makes monetary policy more predictable. They find that interest rates increase on release days, indicating that central bank communication has a conservative bias, while interest rate volatility decreases. They also find evidence that the market's reaction is independent of the content released, although signals of interest rate reduction imply a decrease in volatility.

\section{III}

\section{Communications from the Central Bank of Brazil}

Brazil adopted an inflation-targeting regime in 1999. Since then, the conduct of monetary policy by the Central Bank of Brazil has become more transparent and accountable, and communications more frequent and open, as policymakers realized the importance that expectations play in the economy. This change is consistent with the trend of the world's major central banks, especially those with inflation targeting.

In this paper, I use the information provided through the minutes of COPOM meetings to analyse the Brazilian case. The regular сором meetings are spread over two days, with the first session on Tuesdays and the second session on Wednesdays. On the first day of the meeting, the department heads present an overview of the economic environment. On the second day, the deputy-governors of monetary policy and economic policy present the alternatives for the short-term interest rate and their policy recommendations. Other members of the Board make their own comments and proposals, and then the members vote on a final proposal, with the goal of reaching a consensus decision. The final decision -the Special System of Clearance and Custody (SELIC) rate target and the bias, if any- is then announced.

Eight days after each meeting, the Committee releases the meeting minutes on the central bank's website. The minutes provide a summary of the COPOM discussions. The document describes the state of the economy, what factors were relevant to the decision taken at the meeting and the outlook for future meetings.

Based on all the available information, the agents seek to estimate the state of the economy in the long term and the future behaviour of the policymaker in terms of monetary policy. In this sense, monetary policy and the committee's communications through the minutes will be effective if they can guide agents' expectations.

\section{Estimation}

This section estimates the effects of central bank communications on the short end of the term structure of interest rates in Brazil. Central bank communications are quantified through dummy variables, and the interest rate spread is the difference between an interest rate with a specific maturity up to one year (measured by a swap rate) and the basic interest rate (measured by the SELIC rate) ${ }^{3}$

\footnotetext{
${ }^{3}$ The choice of swap rates as measures of interest rates with different maturities follows the literature on the term structure of interest rates in the Brazilian economy. For example, Lima and Issler (2003), Tabak and Tabata (2004) and Montes and Bastos (2011) use the same swap rates as proxies for long-term interest rates and for the interest rate spread. For more details, see Lima and Issler (2003), Tabak and Tabata (2004) and Montes and Bastos (2011).
} 
For this purpose, the following data were used in the analysis: 360-day swap reference rate, based on the pre-set interbank (DI) rate on the Brazilian Mercantile and Futures Exchange (BM\&F), per cent per year; ${ }^{4}$ 180-day swap reference rate, based on the pre-set DI rate on the BM\&F, per cent per year; 5 120-day swap reference rate, based on the pre-set DI rate on the BM\&F, per cent per year, ${ }^{6}$ and the annualized sELIC interest rate, accumulated in the month. ${ }^{7}$

The period of analysis runs from June 2003 to April 2011, comprising the $85^{\text {th }}$ meeting until the $158^{\text {th }}$ meeting of the COPOM (74 observations). I chose to start with the $85^{\text {th }}$ meeting because until this meeting, there was no clear rule on the disclosure of the minutes of previous meetings. The minutes have only been regularly released since the $85^{\text {th }}$ meeting.

The dummy variables are built based on a prepared glossary (see table A.1 in the appendix), which is intended to codify the words and expressions contained in the minutes of the CоРОм. The glossary was inspired by the work of Rosa and Verga (2007). When there is an indication in the minutes that the COPOM aims to reduce the SELIC rate at its next meeting, the dummy variable dummy_red assumes a value of one (and zero otherwise). When there is an indication that the COPOM will not change the SELIC rate at its next meeting, the dummy variable dummy_neutra assumes a value of one (and zero otherwise). When there is an indication that the COPOM aims to increase the SELIC rate at its next meeting, the dummy variable dummy_aum takes a value of one (and zero otherwise).

To analyse the impact of these communications on the short end of the interest-rate term structure in Brazil, three equations were estimated based on the following basic equation: ${ }^{8}$

$$
\begin{gathered}
\text { Spread }_{k t}=\beta_{1 k} \text { dummy_aum }_{t}+ \\
\beta_{2 k} \text { dummy_neutra }+ \\
+\beta_{3 k} \text { dummy_red }_{t}+\zeta_{k t},
\end{gathered}
$$

where Spread $_{k t}$ is the difference between the swap rate with maturity $k(k=120,180,360)$ and the basic interest rate (SELIC) prevailing at date $t$, and $\zeta_{k t}$ represents the error terms (white noise). The series of Swap_360,Swap_180 and Swap_120 were based on information from the day after the release of the СОРОм minutes on the website

4 Code 7806 (website of the Central Bank of Brazil).

5 Code 7805 (website of the Central Bank of Brazil).

6 Code 7804 (website of the Central Bank of Brazil).

7 Code 4189 (website of the Central Bank of Brazil).

${ }^{8}$ The equations were estimated without the intercept to avoid perfect multi-collinearity. of the Central Bank of Brazil. The expected results are $\beta_{1 k}>0, \beta_{2 k}=0$ (that is, no significance) and $\beta_{3 k}<0$.

The COPOM communications will be effective if interest-rate expectations behave according to the monetary authority's signal, as identified in the minutes. The idea is to check whether monetary policy and communications serve as guides for interest-rate expectations and, as a consequence, affect the short end of the interest-rate term structure in Brazil in the desired direction. The analysis was performed through oLs and VAR using the EViews 7 software.

Table 1 reveals that the estimated coefficients for two of the dummy variables (dummy_aum and dummy_red) are significant for all maturities and present the expected signs. The estimated coefficients for the neutral dummy variable (dummy_neutra) are not statistically significant, which means that when COPOM indicates that it will not change the SELIC rate, spreads do not change.

The evidence presented so far has shown that when the central bank indicates that it will tighten monetary policy, the spreads react by increasing, and when the central bank signals loosening, the spreads decrease. A relevant issue that arises concerns the influence of monetary policy and central bank communications on short-term rates, dynamically. Vector autoregressions (VAR) often employ impulse response functions because they support the evaluation of the impact of shocks (or innovations) on key variables over time (Sims, 1980). As pointed out by Lutkenpohl (1991), the conventional method applies an orthogonality assumption, so the result may depend on the ordering of the variables in the VAR. Koop, Pesaran and Potter (1996) and Pesaran and Shin (1998) develop the idea of the generalized impulse response function as a way of eliminating the problem of the ordering of variables in the vaR. The main argument is that the generalized impulse responses are invariant to any reordering of the variables in the VAR (see, for example, Ewing, 2003).

The analysis uses the SELIC rate, Swap 360 , Swap_180, Swap_120,dummy_red and dummy_aum. Because the different series for Swap_360, Swap_180 and Swap 120 present structural breaks in the averages (as figures A. 1 , A. 2 and A. 3 in the appendix show), the VAR includes a dummy variable (named dummy_break) as an exogenous variable, where dummy_break takes a value of one from meeting 85 until meeting 123, and zero otherwise.

To check if the series are stationary, that is, if the series do not have a unit root, both Kwiatkowski-PhillipsSchmidt-Shin (KPSS) and Phillips-Perron (PP) tests were applied (see tables A.2 and A.3 in the appendix). The Akaike information criterion (AIC), the Schwarz 
TABLE 1

Effect of dummy variables on Spreads

\begin{tabular}{|c|c|c|c|}
\hline \multirow{2}{*}{ Explanatory variables } & \multicolumn{3}{|c|}{ Dependent variables } \\
\hline & Spread $_{120}$ & Spread $_{180}$ & Spread $_{360}$ \\
\hline dummy_aum & $\begin{array}{l}0.45^{* * *} \\
(0.00)\end{array}$ & $\begin{array}{l}0.65 * * * \\
(0.00)\end{array}$ & $\begin{array}{l}0.91 \text { *** } \\
(0.00)\end{array}$ \\
\hline dummy_neutra & $\begin{array}{l}-0.013 \\
(0.89)\end{array}$ & $\begin{array}{c}0.008 \\
(0.94)\end{array}$ & $\begin{array}{c}0.35 \\
(0.10)\end{array}$ \\
\hline dummy_red & $\begin{array}{l}-0.75^{* * *} \\
(0.00)\end{array}$ & $\begin{array}{l}-0.95 * * * \\
(0.00)\end{array}$ & $\begin{array}{l}-1.14 * * * \\
(0.00)\end{array}$ \\
\hline Summary statistics & & & \\
\hline$R^{2}$ & 0.54 & 0.55 & 0.45 \\
\hline Adjusted $R^{2}$ & 0.52 & 0.53 & 0.43 \\
\hline Standard error & 0.48 & 0.62 & 1.01 \\
\hline No. observations & 74 & 74 & 74 \\
\hline
\end{tabular}

Source: author's estimates.

Notes: The equations are estimated using oLs; $p$ values are in parentheses.

*** Statistically significant at the $1 \%$ level.

information criterion (SIC) and the Hannan-Quinn information criterion (HQ) were used to select the VAR order. The results indicate that the VAR order is one (see table A.4 in the appendix). Figure 1 shows the stability of the estimated VAR.

FIGURE 1

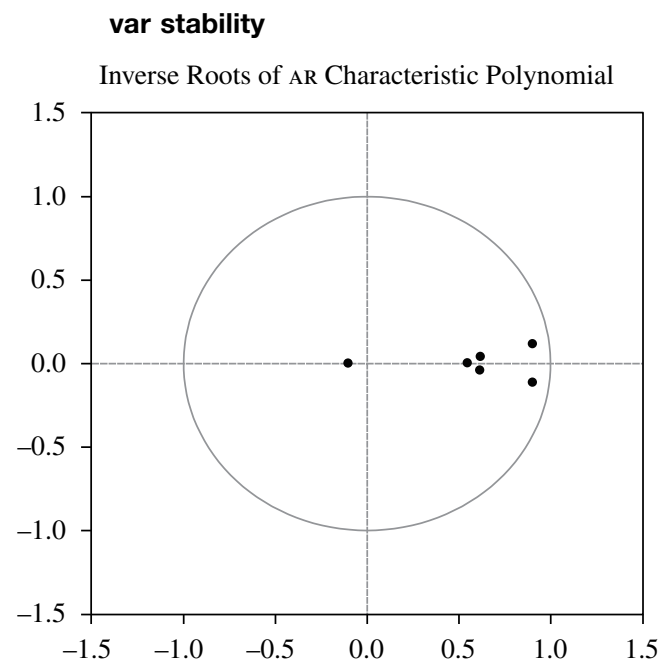

Source: author's elaboration.

Figure 2 presents the results of the generalized impulse response functions for a time horizon of 18 months. The evidence indicates that when the COPOM minutes signal an increase in the SELIC interest rate for the next meeting, interest rates react by first increasing and then converging to equilibrium. When the COPOM signals a reduction in the SELIC interest rate for the next meeting, interest rates react by decreasing and then converging to equilibrium. These findings are statistically significant. Regarding the influence of monetary policy shocks on the short end of the interest-rate term structure, the results suggest that positive shocks on the SELIC interest rate cause an increase in interest rates. Again, these results are statistically significant.

The evidence obtained so far suggests that monetary policy and СОРОм communications play an important role in the process of expectations formation about the behaviour of interest rates in Brazil. Because long-term interest rates also reflect macroeconomic aspects, I next examined the influence of monetary policy and COPOM communications on the short end of the interest-rate term structure, as well as the influence of inflation expectations and output deviations from its trend. To do so, I added the following series: output deviations (the difference between GDP ${ }^{9}$ and trend GDP $)^{10}$ and inflation expectations (market expectations for inflation over the next 12 months, as measured by the Extended National Consumer Price Index (IPCA). ${ }^{11}$

\footnotetext{
9 Code 4191 (website of the Central Bank of Brazil).

10 Obtained through the Hodrick-Prescott filter.

11 Obtained from the Central Bank of Brazil website.
} 
FIGURE 2

Impulse responses to a one-standard-deviation shock ( \pm 2 standard errors)

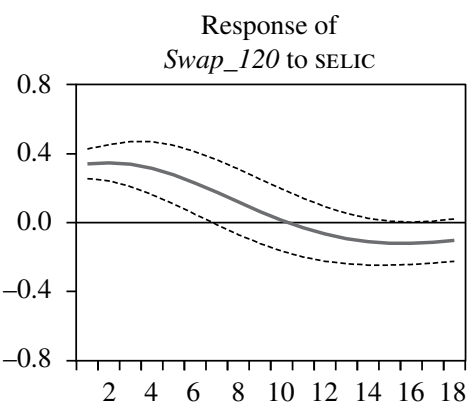

Response of

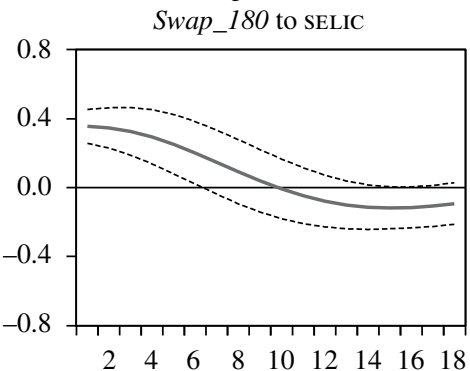

Response of

Swap_360 to SELIC

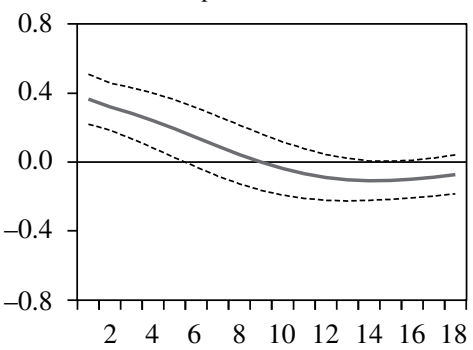

Response of

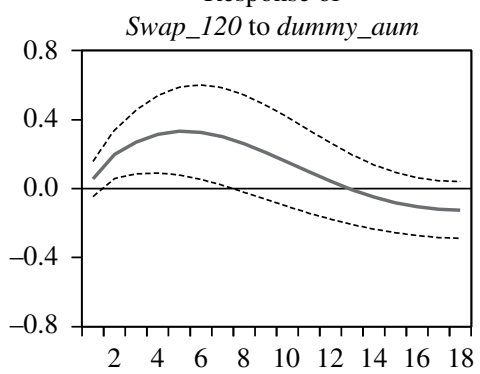

Response of

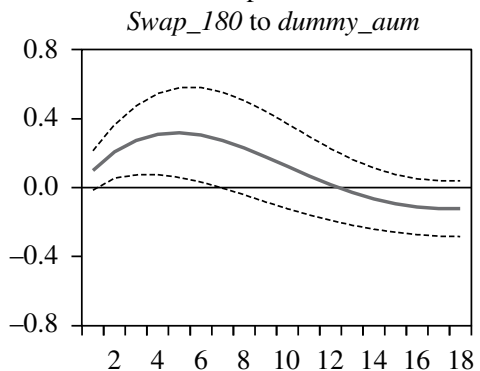

Response of Swap_360 to dummy_aum

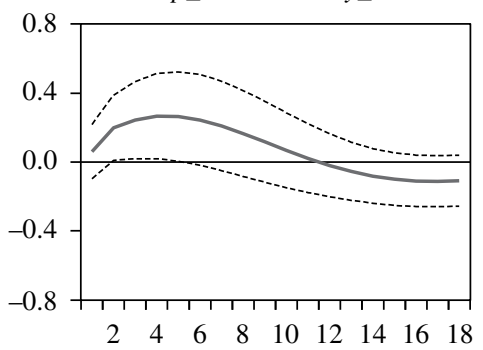

Response of

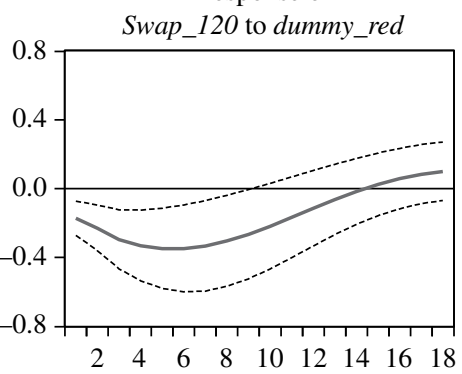

Response of

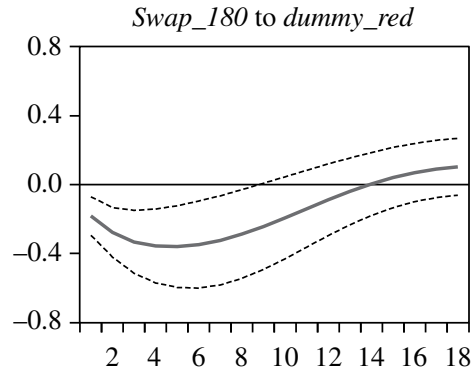

Response of

Swap_360 to dummy_red

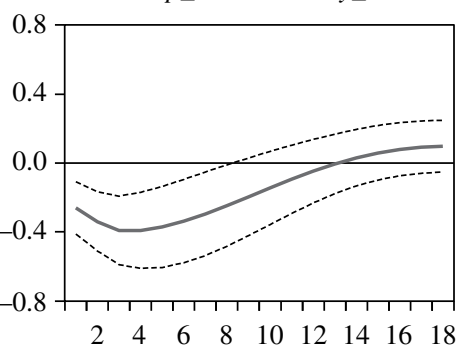

Source: author's elaboration.

I then estimated the following equation, based on Fuhrer and Moore (1995a and 1995b), Fuhrer (1996) and Walsh (2010), to analyse the influence of monetary policy, central bank communications, output deviations and inflation expectations on short-term rates:

$$
\begin{gathered}
S_{k t}=\alpha_{k} \pi_{t-1}^{e}+\delta_{k}\left(y_{t-1}-y_{t-1}^{*}\right)+\gamma_{k}\left(r_{t-1}\right)+ \\
\text { communication_dummies }{ }_{t}+\varepsilon_{k t}
\end{gathered}
$$

where $S$ is the swap rate with maturity $k(k=120$, $180,360), \pi^{e}$ represents inflation expectations (twelve months ahead), $\left(y-y^{*}\right)$ represents output deviations from trend (which is a measure of the economic cycle), $r$ is basic interest rate (SELIC) and $\varepsilon$ is the error term. The macroeconomic variables were used with a lag, because this is the set of information available to economic agents when they form their expectations for interest rates. The expected signs for the coefficients of the macroeconomic variables are $\alpha>0 ; \delta>0$ and $\gamma>$ 0 . The communication_dummies are the same dummy variables used before (dummy_aum,dummy_red and dummy_neutra). The period of the study runs from June 2003 to April 2011, comprising the $85^{\text {th }}$ through the $158^{\text {th }}$ meeting of the COPOM. 
The empirical analysis was conducted using ordinary least squares (OLS) ${ }^{12}$ and generalized method of moments (GMM). One reason for using GMM is that while OLS estimates have problems of serial autocorrelation, heteroskedasticity or non-linearity, which is typical in macroeconomic time series, GMM provides consistent estimators for the regression (Hansen, 1982).

According to Wooldridge (2001, p. 95), "to obtain a more efficient estimator than two-stage least squares (or ordinary least squares), one must have overriding restrictions." I used a standard J-test to test this property for the validity of the overidentifying restrictions (Hansen, 1982). Cragg (1983) argues that using overidentification analysis in the selection of instrumental variables improves the efficiency of the estimators. The chosen instruments need to be dated to the period $t-1$ or earlier to help predict the contemporaneous variables, which are unavailable at time $t$. This procedure for choosing instrumental variables follows Johnston (1984). ${ }^{13}$

A first condition to be analysed before applying the estimations is to check whether the series are stationary. Based on the tests, while the series of inflation expectations is $\mathrm{I}(1)$, all other series are $\mathrm{I}(0)$ (see tables A.2 and A.3 in the appendix).

\section{Results}

Tables 2, 3 and 4 present the results. The estimates show that for all specifications, the constant is positive and statistically significant, except for equation $\left(S_{120}\right.$ a) which is not statistically significant. Regarding the dummy_break, all estimated coefficients are positive and statistically significant, except those estimated in equations $\left(S_{120}\right.$ e) by OLs and ( $\left.S_{120} \mathrm{~d}\right)$ by GMM which are not statistically significant.

With regard to inflation expectations, the results show that all the estimated coefficients in table 2 are positive, although those present in equations $\left(S_{120} \mathrm{c}\right)$, $\left(S_{120} \mathrm{~d}\right)$ and $\left(S_{120} \mathrm{f}\right)$ by oLs and $\left(S_{120} \mathrm{c}\right)$ and $\left(S_{120} \mathrm{f}\right)$ by GMM are not statistically significant. In table 3 , the oLs estimates indicate a positive relationship between

\footnotetext{
12 The reported t-statistics in the ols estimates are based on the estimator of Newey and West (1987), which is consistent in the presence of both heteroskedasticity and autocorrelation of unknown form.

13 The GMM estimations apply the following instrumental variables:

- For Swap_120: constant, $S_{t}^{120}(-1$ to -3$), \mathrm{d}_{\pi^{\mathrm{e}}}(-2$ to -7$),\left(y-y^{*}\right)$ $(-2$ to -4$)$ and $r(-2$ to -8$)$

- For Swap_180: constant, $S_{t}^{180}(-1$ to -3$), \mathrm{d}_{\pi^{\mathrm{e}}}(-2$ to -7$),\left(y-y^{*}\right)$ $(-2$ to -4$)$ and $r(-2$ to -8$)$

- For Swap_360: constant, $S_{t}^{360}(-1$ to -3$), \mathrm{d}_{\pi^{\mathrm{e}}}(-2$ to -7$),\left(y-y^{*}\right)$ (-2 to -4$)$ and $r(-2$ to -8$)$
}

inflation expectations and Swap_180, although it is not statistically significant in equation $\left(S_{180} \mathrm{~d}\right)$. With GMM, the estimated coefficients in equations $\left(S_{180} \mathrm{a}\right),\left(S_{18} \mathrm{~b}\right)$, $\left(S_{120} \mathrm{~d}\right),\left(S_{120} \mathrm{e}\right)$ and $\left(S_{120} \mathrm{f}\right)$ are all positive and statistically significant. The results for Swap_360 show positive, statistically significant coefficients in all specifications of both methods (see table 4). The economic explanation for the positive relation between inflation expectations and short-term rates is that the expectation of higher inflation leads to expectations that the central bank will tighten monetary policy by raising short-term interest rates in the future to slow economic growth and dampen inflationary pressures. Moreover, inflation expectations have the strongest impact on the longer-term interest rates of the short end of the term structure. This is basically due to the fact that inflation expectations are market expectations for the next 12 months.

The estimates presented in tables 2, 3 and 4 also show the positive influence of output deviations on shortterm rates. All specifications in table 2 are statistically significant, whereas in tables 3 and 4, specifications $\left(S_{180} \mathrm{a}\right),\left(S_{360} \mathrm{a}\right)$ and $\left(S_{360} \mathrm{c}\right)$ by both oLs and by GMM are not statistically significant. The positive relation between output deviations (a measure of the business cycle) and short-term rates is explained as follows: when the economy warms up, inflationary pressures rise, leading economic agents to expect higher interest rates in the future.

Monetary policy has a direct relationship with the short end of the term structure, that is, when the SELIC rate increases, swap rates also rise. Based on the values of the estimated coefficients, this impact is smaller on longer-term interest rates. In this sense, the monetary policy of the Central Bank of Brazil, through the SELIC rate, exerts significant influence on the short end of the term structure.

The central bank's communications also have a positive impact on short rates. The dummy variable for an upward signal, dummy_aum, has a positive, statistically significant effect on the short end of the term structure. In other words, when the СОРОм minutes reveal information that indicates a possible increase in the SELIC interest rate at the next meeting, short-term rates, as measured by swap rates, increase. A comparison of the Swap_120 and Swap_360 variables suggests that communications indicating tighter monetary policies in the future have a stronger effect on the 360-day swap rate than on the 120-day swap rate.

For a downward signal, the results for dummy_red reveal a negative, statistically significant impact on the short end of the term structure. When the Brazilian 


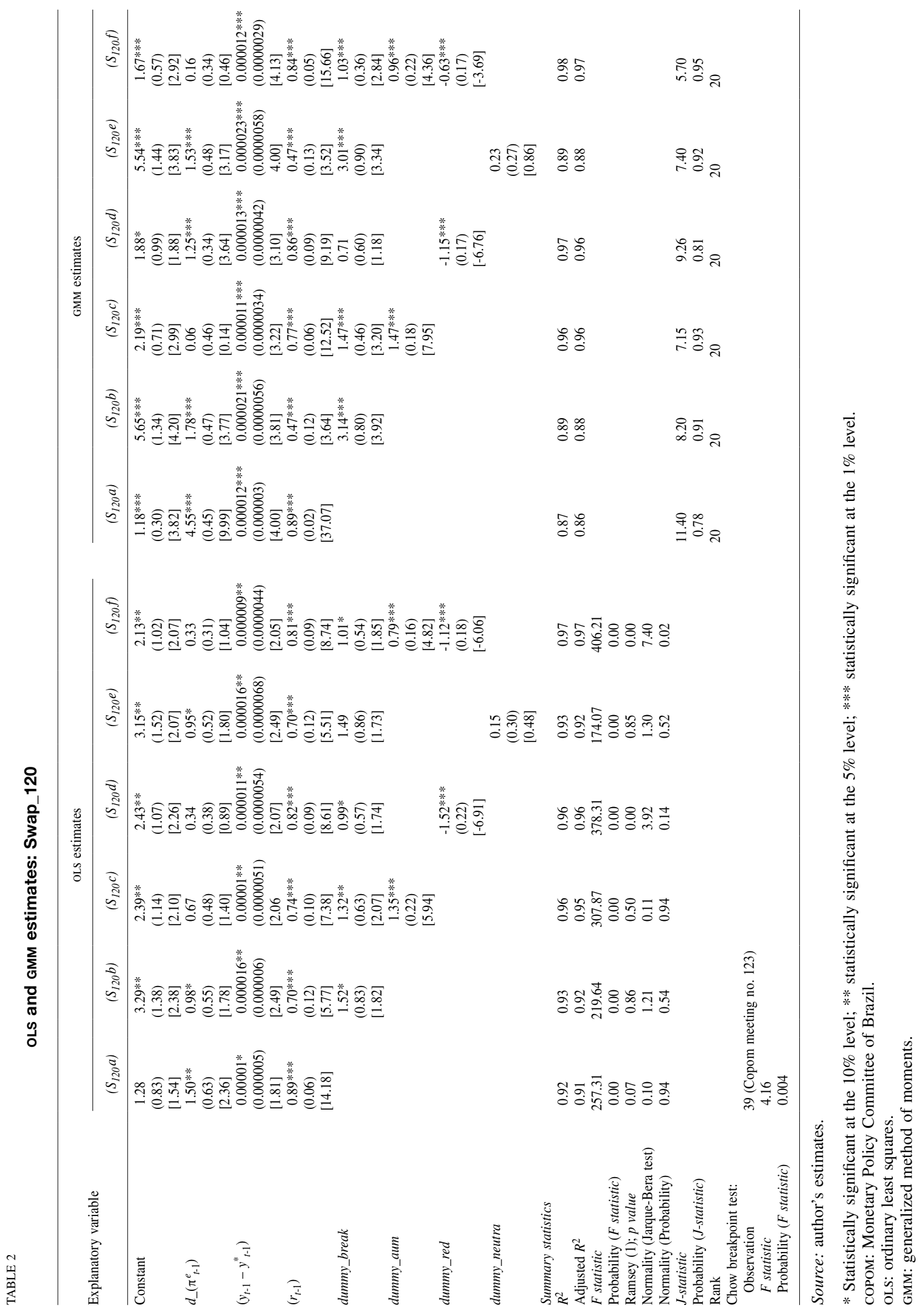




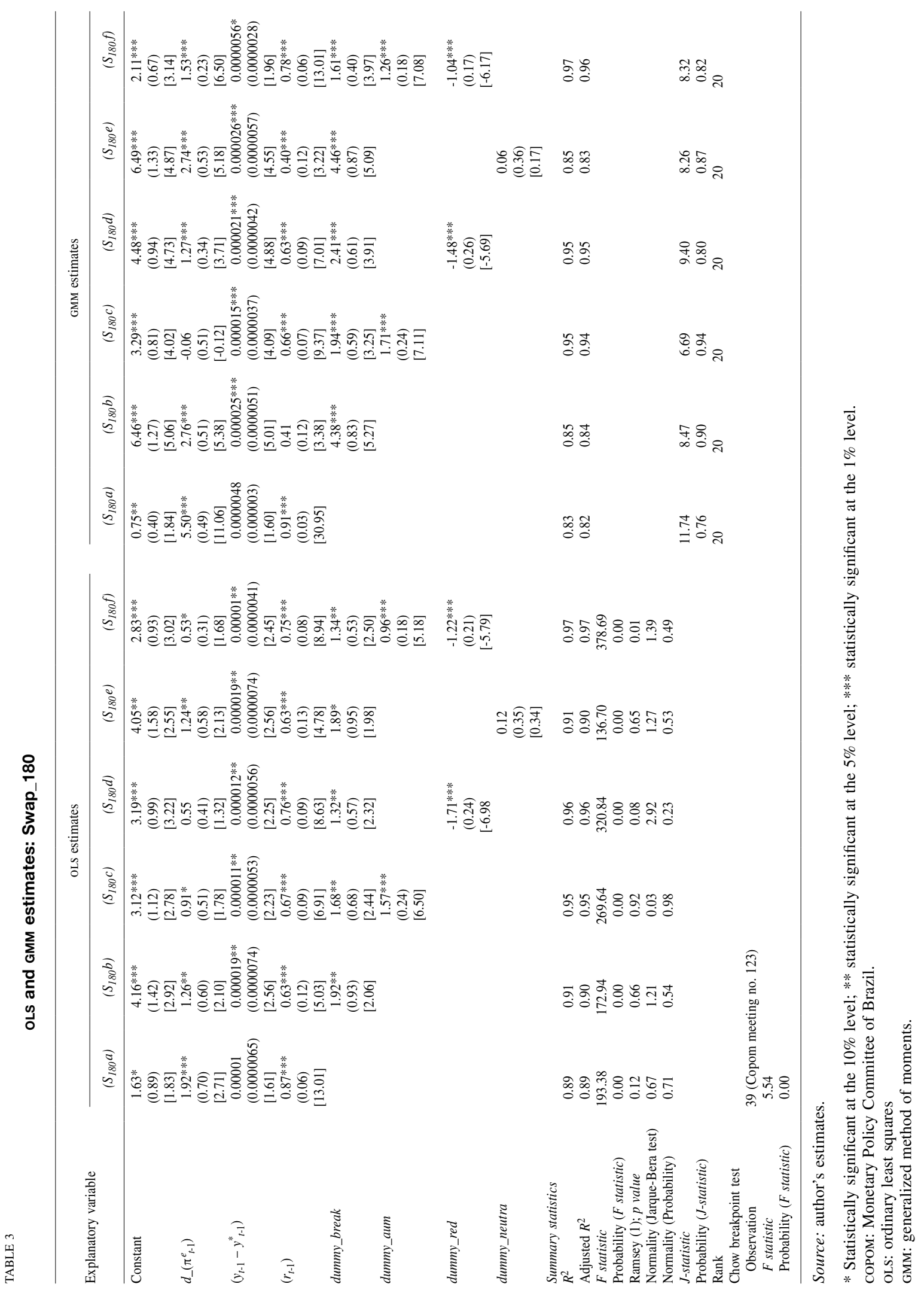




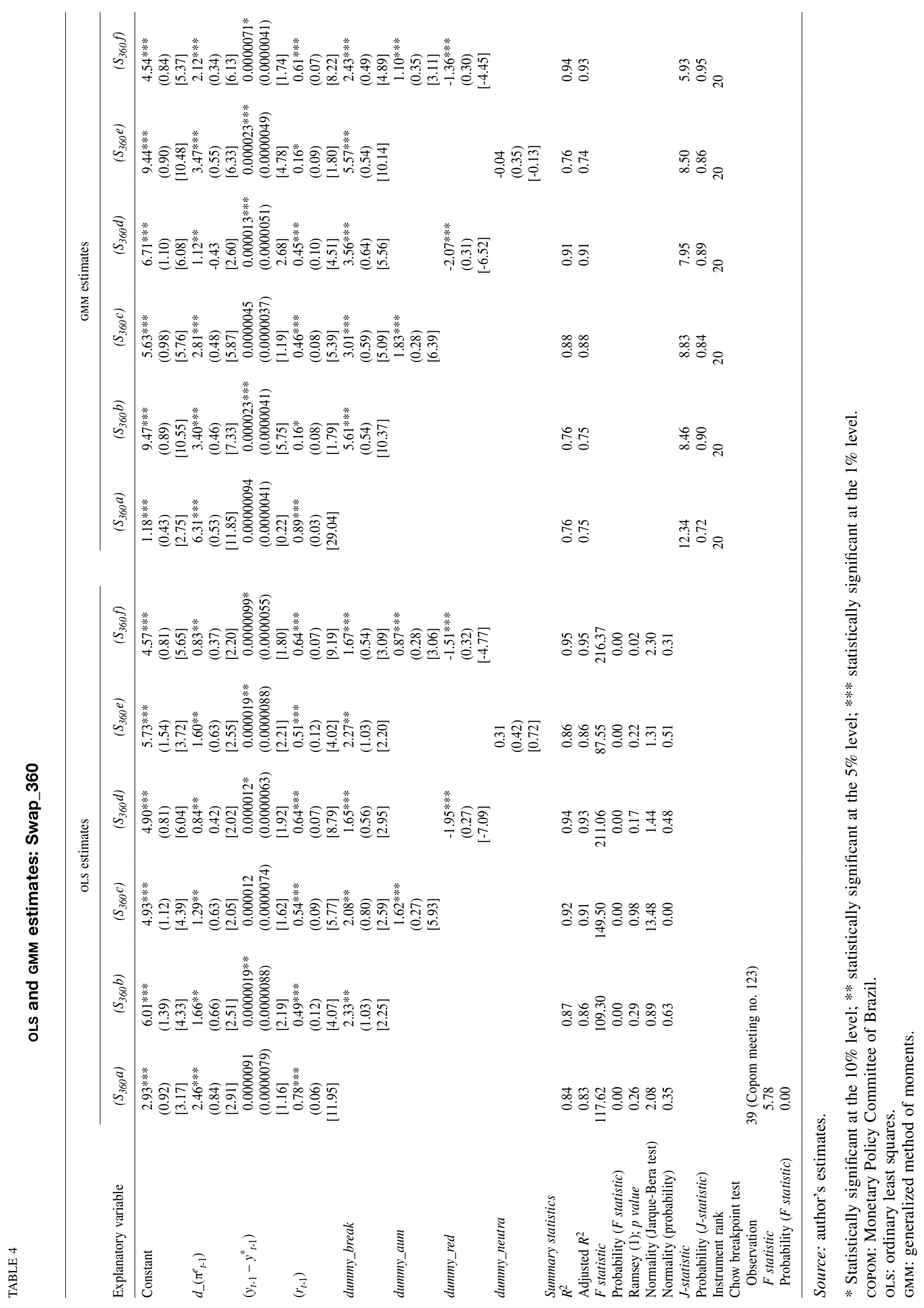


Monetary Policy Committee indicates a possible decrease in the SELIC rate at the next meeting, interest rates, as measured by swap rates, decrease. Once again, the results suggest that communications have a stronger effect on the 360-day rate than on the 120-day rate.

\section{IV}

\section{Conclusions}

Communication gives the Central Bank of Brazil a means of explaining its intentions, decisions and rationale. Because the central bank's inflation-targeting framework allows discretion, communication becomes an important tool for local policymakers to explain their decisions and help economic agents understand how the Central Bank of Brazil views the state of the economy and the economic outlook. Economic agents are then better able to formulate their expectations, which has a direct effect on financial market variables.

To contribute to the literature on the effect of central bank communications and monetary policy on financial markets, this study has analysed the influence of these factors on the term structure of interest rates in Brazil. The study shows that monetary policy actions and communications by the Brazilian monetary authority have a significant impact on the process of expectations formation for interest rates with different maturities in Brazil. Not only do financial markets respond to the publication of the COPOM minutes, but they move in the desired direction. In this sense, the minutes of соРОм meetings serve as an important tool for guiding expectations for interest rates, since economic agents use the minutes of COPOM meetings to estimate the future state of the economy, which reduces uncertainty about future monetary policy actions.

The results highlight the beneficial effects of communication in providing information to the general public and to the markets in particular, thus serving as an important instrument of the central bank. According to the evidence found in this work, the relevance of communication by the monetary authority lies in its ability to affect expectations for future interest rates, which in turn inform several key decisions of economic agents. This is because monetary policy decisions affect
None of the coefficients estimated for dummy_neutra are statistically significant. This means that when COPOM signals that the SELIC interest rate will not be changed at the next meeting, interest rates, as measured by swap rates, do not change as a result.

short-term interest rates, while the relevant variables for monetary policy are influenced by long-term interest rates. Since these interest rates are determined by expectations about the future course of the short-term interest rates, the importance of central bank communication lies in its ability to affect market expectations.

Central bank communication is not the only variable determining the process of expectations formation in financial markets. Other variables also play a role. Therefore, in addition to exploring the impact of monetary policy and communications on interest-rate expectations, the study also analysed the effects of macroeconomic variables, such as output fluctuations and inflation expectations. Future research could expand the model to consider the conduct of other economic policies, such as fiscal policy by incorporating variables such as the debt-to-GDP ratio, the debt profile and fiscal credibility.

The financial market reaction to monetary policy and central bank communications is undoubtedly a topic of great interest to market participants and central banks. Investors are interested in anticipating the central bank's decisions because such decisions may affect the value of their portfolios, while the central bank seeks to estimate the likely effect of monetary policy on asset prices and on the economy as a whole. Future research could productively incorporate not only the topics suggested by Blinder and others (2008), but also the influence of central bank communications on monetarypolicy transmission mechanisms through the following channels: (1) financial asset prices and, hence, investment and consumption decisions through the wealth effect; (2) credit, through banks' postures and credit decisions; and (3) expectations for macroeconomic variables, such as inflation expectations, exchange-rate expectations and output growth expectations.

(Original: English) 
APPENDIX

Supplementary tables and figures

TABLE A.1

Glossary of key words and expressions from minutes of copom meetings

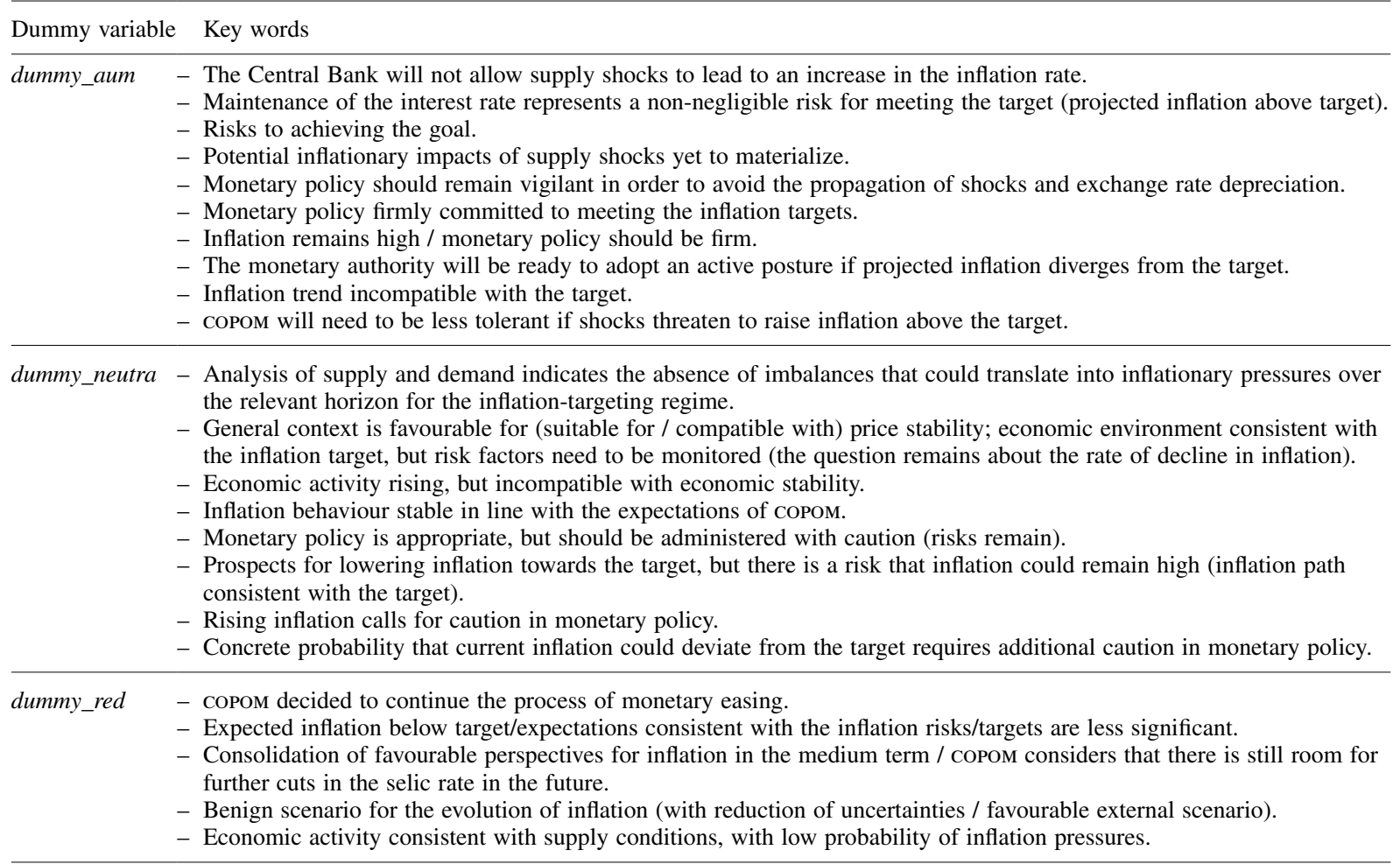

Source: author's elaboration.

COPOM: Monetary Policy Committee of Brazil.

SELIC: Special System of Clearance and Custody.

TABLE A.2

Kwiatkowski-Phillips-Schmidt-Shin (KPSS) stationarity test

\begin{tabular}{|c|c|c|c|c|c|}
\hline Series & Bandwidth & Test & $1 \%$ critical values & $5 \%$ critical values & $10 \%$ critical values \\
\hline Swap_120 & 6 & $0.08^{b}$ & 0.21 & 0.14 & 0.11 \\
\hline Swap_180 & 6 & $0.08^{b}$ & 0.21 & 0.14 & 0.11 \\
\hline Swap_360 & 6 & $0.08^{\mathrm{b}}$ & 0.21 & 0.14 & 0.11 \\
\hline Spread $_{120}$ & 6 & $0.07^{b}$ & 0.21 & 0.14 & 0.11 \\
\hline Spread $_{180}$ & 6 & $0.07^{b}$ & 0.21 & 0.14 & 0.11 \\
\hline Spread $_{360}$ & 6 & $0.07^{b}$ & 0.21 & 0.14 & 0.11 \\
\hline Inflation expectation & 6 & $0.22^{\mathrm{b}}$ & 0.21 & 0.14 & 0.11 \\
\hline$d$ (inflation expectation) & 2 & $0.04^{\mathrm{b}}$ & 0.21 & 0.14 & 0.11 \\
\hline Output gap & 5 & $0.03^{\mathrm{a}}$ & 0.73 & 0.46 & 0.34 \\
\hline SELIC rate & 6 & $0.06^{\mathrm{b}}$ & 0.21 & 0.14 & 0.11 \\
\hline
\end{tabular}

Source: author's estimates.

Notes: Andrews automatic bandwidth selection, using Bartlett kernel. Schwarz information criteria (SIC).

SELIC: Special System of Clearance and Custody.

a denotes constant.

b denotes constant and trend. 
TABLE A.3

Phillips-Perron (pp) unit root test

\begin{tabular}{|c|c|c|c|c|c|}
\hline Series & Bandwidth & Test & $1 \%$ critical values & $5 \%$ critical values & $10 \%$ critical values \\
\hline Swap_120 & 6.51 & $-1.738^{c}$ & -2.597 & -1.945 & -1.613 \\
\hline Swap_180 & 5.99 & $-1.654^{\mathrm{c}}$ & -2.597 & -1.945 & -1.613 \\
\hline Swap_360 & 2.51 & $-1.614^{\mathrm{c}}$ & -2.597 & -1.945 & -1.613 \\
\hline Spread $_{120}$ & 1.70 & $-3.647^{c}$ & -2.597 & -1.945 & -1.613 \\
\hline Spread & 1.37 & $-3.525^{c}$ & -2.597 & -1.945 & -1.613 \\
\hline Spread $_{360}$ & 0.08 & $-3.416^{c}$ & -2.597 & -1.945 & -1.613 \\
\hline Inflation expectation & 3.06 & $-2.378^{a}$ & -3.522 & -2.901 & -2.588 \\
\hline$d$ (inflation expectation) & 0.72 & $-7.150^{\mathrm{c}}$ & -2.597 & -1.945 & -1.613 \\
\hline Output gap & 3.69 & $-3.304^{c}$ & -2.597 & -1.945 & -1.613 \\
\hline SELIC rate & 14.5 & $-2.849^{\mathrm{a}}$ & -3.522 & -2.901 & -2.588 \\
\hline
\end{tabular}

Source: author's estimates.

Notes: Andrews automatic bandwidth selection, using Bartlett kernel. Schwarz information criteria (SIC).

SELIC: Special System of Clearance and Custody.

a denotes constant.

b denotes constant and trend.

c denotes none.

TABLE A.4

aic, sc and hq criteria for var lag order

\begin{tabular}{ccccccc}
\hline \multirow{2}{*}{ VAR lag order } & \multicolumn{3}{c}{ With constant } & & \multicolumn{2}{c}{ Without constant } \\
\cline { 2 - 6 } & AIC & SIC & HQ & AIC & SIC & HQ \\
\hline 0 & 7.74 & 7.94 & 7.82 & & \\
1 & -0.13 & $1.23^{*}$ & $0.40^{*}$ & $-0.03^{*}$ & $1.13^{*}$ & $0.42^{*}$ \\
2 & 0.14 & 2.68 & 1.15 & 0.25 & 2.60 & 1.18 \\
3 & 0.29 & 4.01 & 1.77 & 0.49 & 4.01 & 1.88 \\
4 & 0.53 & 5.42 & 2.47 & 0.82 & 5.52 & 2.68 \\
5 & 0.27 & 6.34 & 2.67 & 0.57 & 6.44 & 2.89 \\
6 & -0.24 & 7.00 & 2.62 & 0.01 & 7.06 & 2.81 \\
\hline
\end{tabular}

Source: author's estimates.

Notes: Akaike information criterion (AIC); Schwarz information criterion (SIC);Hannan-Quinn (HQ) information criterion. An asterisk indicates the lag order selected by respective criterion. 
FIGURE A.1

Structural break: Swap_120

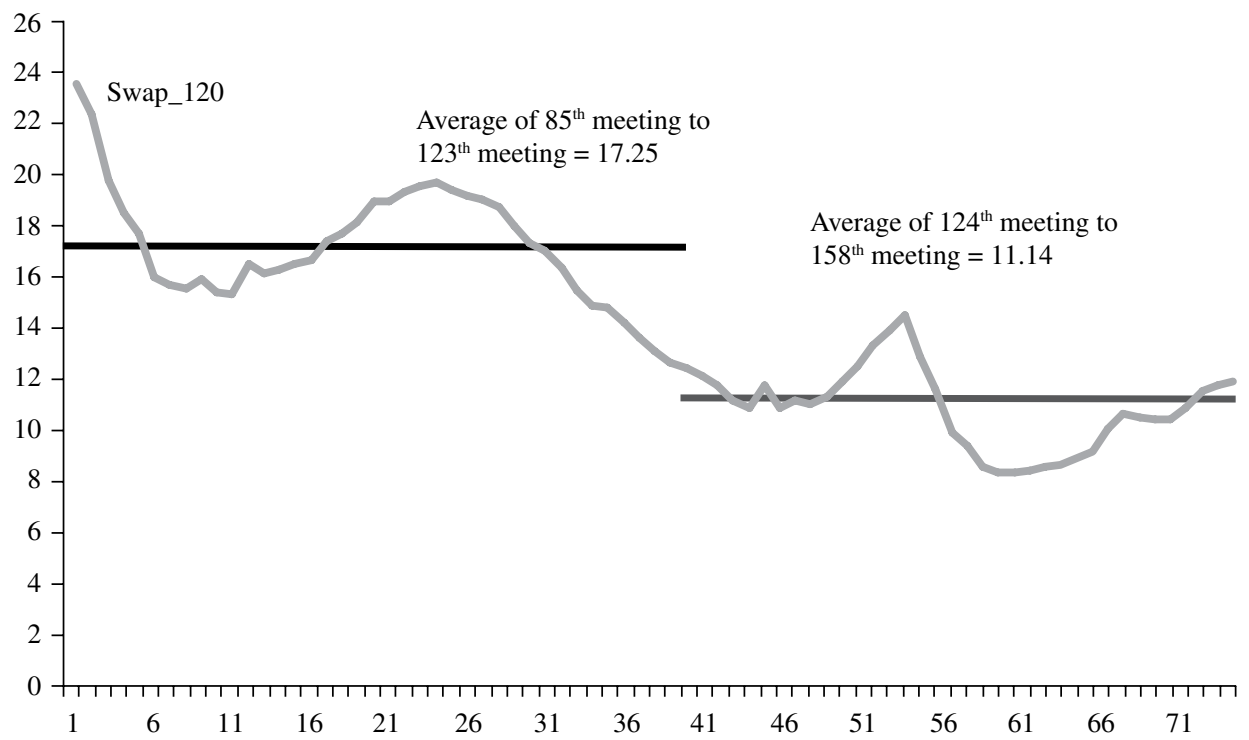

Source: author's elaboration.

FIGURE A.2

Structural break: Swap_180

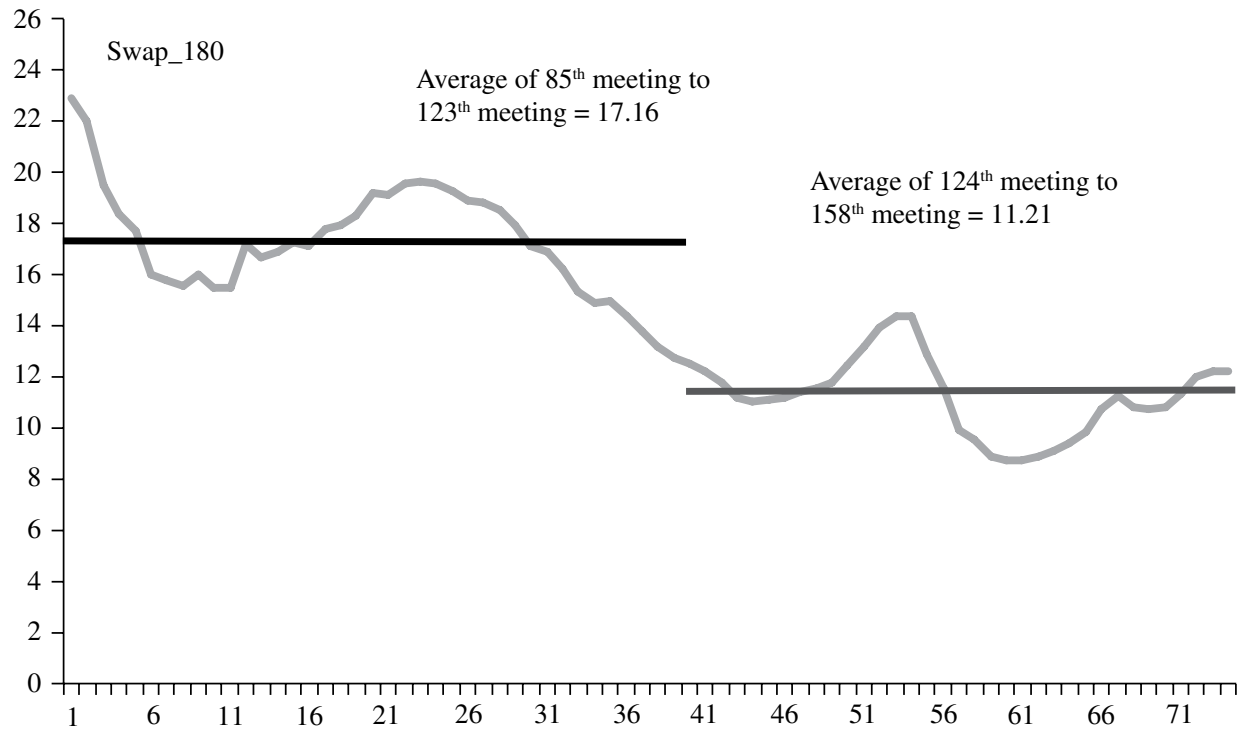

Source: author's elaboration. 
FIGURE A. 3

Structural break: Swap_360

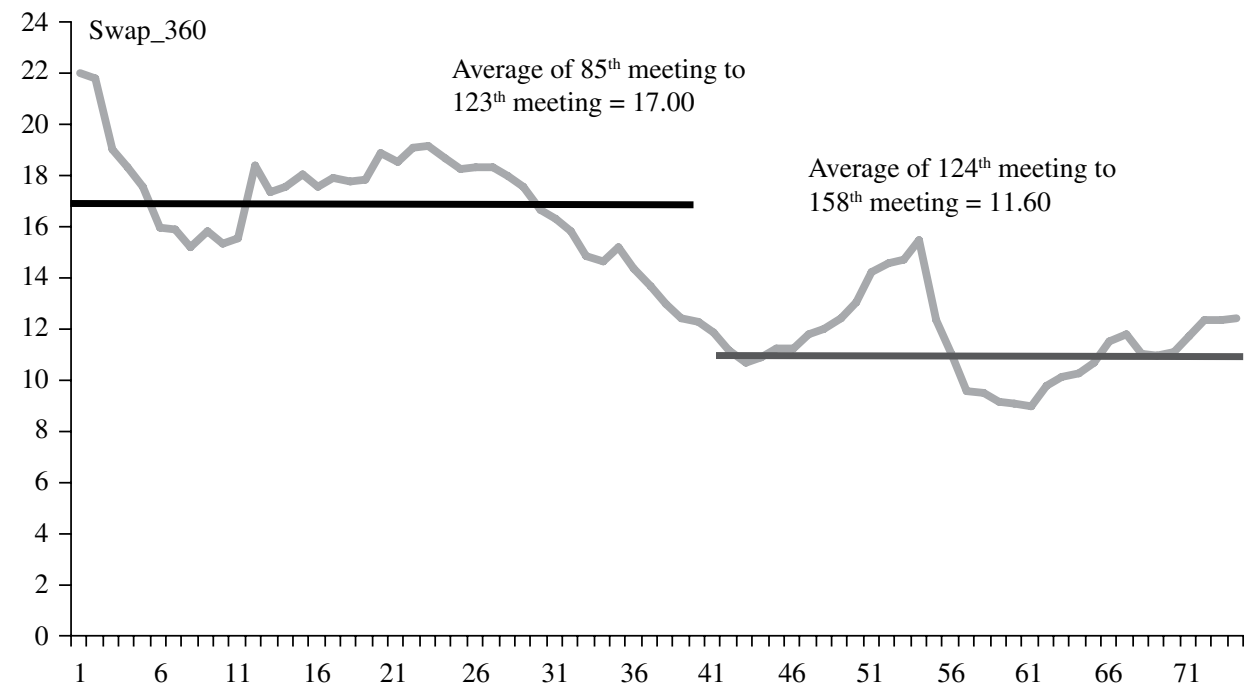

Source: author's elaboration.

Andersson, M., H. Dillén and P. Sellin (2006), "Monetary policy signaling and movements in the Swedish term structure of interest rates", Journal of Monetary Economics, vol. 53, No. 8, Amsterdam, Elsevier.

Berger, H., J. de Haan and J-E. Sturm (2011), "Does money matter in the ECB strategy? New evidence based on ECB communication", International Journal of Economics and Finance, vol. 16, No. 1, John Wiley \& Sons.

Blinder, A. and others (2008), "Central Bank communication and monetary policy: a survey of theory and policy", Journal of Economic Literature, vol. 46, No. 4, Nashville, Tennessee, American Economic Association.

Brand, C., D. Buncic and J. Turunen (2010), "The impact of ЕСB monetary policy decisions and communication on the yield curve", Journal of the European Economic Association, vol. 8, No. 6, Cambridge, Massachusetts, The MIT Press.

Connolly, E. and M. Kohler (2004), "News and interest rate expectations: a study of six central banks", rba Research Discussion Paper, 04-10, Sydney, Reserve Bank of Australia.

Cook, T. and T. Hahn (1989), "The effect of changes in the federal funds rate target on market interest rates in the 1970s", Journal of Monetary Economics, vol. 24, No. 3, Amsterdam, Elsevier.

Costa Filho, A.E. and F. Rocha (2010), "Como o mercado de juros futuro reage a comunicação do banco central?", Economia aplicada, vol. 14, No. 3 .

(2009), "Comunicação e política monetária no el Brasil", Revista brasileira de economia, vol. 63, No. 4, Rio de Janeiro, Getulio Vargas Foundation.

Cragg, J.G. (1983), "More efficient estimation in the presence of heteroscedasticity of unknown form", Econometrica, vol. 51, No. 3, New York, Econometric Society.

De Mendonça, H.F. and J. Simão-Filho (2007), "Economic transparency and effectiveness of monetary policy", Journal of Economic Studies, vol. 34, No. 6, Emerald Group Publishing.
Ehrmann, M. and M. Fratzscher (2009), "Explaining monetary policy decisions in press conferences", International Journal of Central Banking, vol. 5, No. 2, San Francisco.

(2007a), "The timing of central bank communication", European Journal of Political Economy, vol. 23, No. 1, Amsterdam, Elsevier.

(2007b), "Communication by Central Bank Committee members: different strategies, same effectiveness", Journal of Money, Credit and Banking, vol. 39, No. 2-3, Blackwell Publishing.

Evans, C.L. and D.A. Marshall (1998), "Monetary policy and the term structure of nominal interest rates: evidence and theory", Carnegie-Rochester Conference Series on Public Policy, vol. 49, No. 1, Amsterdam, Elsevier.

Ewing, B.T. (2003), "The response of the default risk premium to macroeconomic shocks", The Quarterly Review of Economics and Finance, vol. 43, No. 2, Amsterdam, Elsevier.

Fuhrer, J.C. (1996), "Monetary policy shifts and long term interest rates", Quarterly Journal of Economics, vol. 111, No. 4, Cambridge, Massachusetts, The MIT Press.

Fuhrer, J.C. and G.R. Moore (1995a), "Inflation persistence", Quarterly Journal of Economics, vol. 110, No. 1, Cambridge, Massachusetts, The MIT Press.

(1995b), "Monetary policy trade-offs and the correlation between nominal interest rates and real output", The American Economic Review, vol. 85, No. 1, Nashville, Tennessee, American Economic Association.

Fujiwara, I. (2005), "Is the Central Bank's publication of economic forecasts influential?", Economics Letters, vol. 89, No. 3, Amsterdam, Elsevier.

Geraats, P. (2002), "Central Bank transparency", The Economic Journal, vol. 112, No. 483, Wiley.

Haldane, A.G. and V. Read (2000), "Monetary policy surprises and the yield curve", Bank of England Working Paper, No. 106, London, Bank of England. 
Hansen, L.P. (1982), "Large sample properties of generalized method of moments estimators", Econometrica, vol. 50, No. 4, New York, Econometric Society.

Hayo, B., A. Kutan and M. Neuenkirch (2010), "The impact of U.S. central bank communication on European and pacific equity markets", Economics Letters, vol. 108, No. 2, Amsterdam, Elsevier.

Hayo, B. and M. Neuenkirch (2010), "Do Federal Reserve communications help predict federal funds target rate decisions?", Journal of Macroeconomics, vol. 32, No. 4, Amsterdam, Elsevier

Jansen, D. and J. de Haan (2005), "Talking heads: the effects of ECB statements on the euro-dollar exchange rate", Journal of International Money and Finance, vol. 24, No. 2, Amsterdam, Elsevier.

Johnston, J. (1984), Econometric Methods, Singapur, McGraw-Hill.

Kohn, D.L. and B. Sack (2004), "Central bank talk: does it matter and why?", Macroeconomics, Monetary Policy, and Financial Stability, Ottawa, Bank of Canada.

Koop, G., M.H. Pesaran and S.M. Potter (1996), "Impulse response analysis in non-linear multivariate models", Journal of Econometrics, vol. 74, No. 1, Amsterdam, Elsevier.

Lima, A. and J. Issler (2003), "A hipótese das expectativas na estrutura a termo de juros no el Brasil: uma aplicação de modelos de valor presente", Revista brasileira de economia, vol. 57, No. 4, Rio de Janeiro, Getulio Vargas Foundation.

Lutkenpohl, H. (1991), Introduction to Multiple Time Series Analysis, Berlin, Springer.

Mishkin, F.S. and M.A. Savastano (2001), "Monetary policy strategies for Latin America", Journal of Development Economics, vol. 66, No. 2, Amsterdam, Elsevier.

Montes, G.C. and J.C.A. Bastos (2011), "Metas de inflação e estrutura a termo das taxas de juros no el Brasil", Economia aplicada, vol. 15, No. 3, São Paulo.

Musard-Gies, M. (2006), "Do ECB's statements steer short-term and long-term interest rates in the Euro-Zone?", The Manchester School, vol. 74 (supplement), Wiley.

Newey, W.K. and K.D. West (1987), "A simple, positive semidefinite, heteroskedasticity and autocorrelation consistent covariance matrix", Econometrica, vol. 55, No. 3, New York, Econometric Society.
Pesaran, M.H. and Y. Shin (1998), "Generalized impulse response analysis in linear multivariate models", Economics Letters, vol. 58, No. 1, Amsterdam, Elsevier.

Ranaldo, A. and E. Rossi (2010), "The reaction of asset markets to Swiss National Bank communication", Journal of International Money and Finance, vol. 29, No. 3, Amsterdam, Elsevier.

Reeves, R. and M. Sawicki (2007), "Do financial markets react to Bank of England communication?", European Journal of Political Economy, vol. 23, No. 1, Amsterdam, Elsevier.

Roley, V. and G. Sellon (1995), "Monetary policy actions and long term interest rates", Economic Review, Kansas, Federal Reserve Bank of Kansas City.

Rosa, C. (2011), "Talking less and moving the market more: evidence from the Есв and the Fed", Scottish Journal of Political Economy, vol. 58, No. 1, Wiley.

Rosa, C. and G. Verga (2007), "On the consistency and effectiveness of Central Bank communication: evidence from the ECB", European Journal of Political Economy, vol. 23, No. 1, Amsterdam, Elsevier.

Rozkrut, M. and others (2007), "Quest for Central Bank communication. Does it pay to be "talkative?", European Journal of Political Economy, vol. 23, No. 1, Amsterdam, Elsevier.

Sims, C. (1980), "Macroeconomics and reality", Econometrica, vol. 48, No. 1, New York, Econometric Society.

Sturm, J.-E. and J. De Haan (2011), "Does central bank communication really lead to better forecasts of policy decisions? New evidence based on a Taylor rule model for the ECB", Review of World Economics, vol. 147, No. 1, Springer.

Tabak, B.M. and A. Tabata (2004), "Surpresas na política monetária e a estrutura a termo da taxa de juros brasileira", Revista de economia aplicada, vol. 8, No. 3 .

Walsh, C.E. (2010), Monetary Theory and Policy, Cambridge, Massachusetts, The MIT Press.

Woodford, M. (2003), Interest and Prices: Foundations of a Theory of Monetary Policy, Princeton, Princeton University Press.

Wooldridge, J.M. (2001), "Applications of generalized method of moments estimation", Journal of Economic Perspectives, vol. 15, No. 4, Nashville, Tennessee, American Economic Association. 